UDC $378.14+004.9$

Svitlana O. Sysoieva

Doctor of Pedagogical Sciences, Professor,

Academician-Secretary at the Department of General Pedagogy and Philosophy of Education

National Academy of Educational Sciences of Ukraine, Kyiv, Ukraine

ORCID ID 0000-0003-2499-732X

s.sysoieva@kubg.edu.ua

Kateryna P. Osadcha

$\mathrm{PhD}$ of Pedagogical Sciences, Associate Professor,

Associate Professor at the Department of Computer Science and Cybernetics

Bogdan Khmelnitsky Melitopol State Pedagogical University, Melitopol, Ukraine

ORCID ID 0000-0003-0653-6423

okp@mdpu.org.ua

\title{
FORMATION OF THE TUTOR ICT-COMPETENCE IN THE PROCESS OF FUTURE TEACHERS' PROFESSIONAL TRAINING
}

\begin{abstract}
The widespread proliferation of information and communication technologies and the task of meeting the sustainable development goals by overcoming the uneven access of the younger generation to information and communication technologies require the presence of the high level of the ICT competence and the ability to carry out tutoring activities in the information society for teachers-to-be. The paper offers the methodological approaches (contents, methods, tools, and technologies) of forming the tutor ICT competence in the process of future teachers' professional training. The educational content, which aims at building the ICT competence of teachers as tutors is distributed over the entire period of students' study at higher educational institutions. During the study of compulsory subjects in the Bachelor program and the "Organization of distance learning in the educational institution" elective discipline in the Master program, students are familiarized with theoretical and methodological aspects of the use of ICT in tutoring. The main method of forming the tutor ICT competence is the portfolio method, in particular, the use of e-portfolio. As the main means of the formation of the tutor ICT competence, computer training programs, e-resources, Internet resources, mobile applications, virtual and augmented reality are determined. E-mail, blogs, social networks, webinars, chats have been used as the technologies of network interaction for forming the tutor ICT competence. In order to identify effective methodological approaches to the formation of the ICT competence of future teachers as tutors, the study has been conducted based on the collection of information by means of questionnaires and statistical processing of the results. The analysis of the results of the pedagogical experiment and comparison of indicators of control and experimental groups before and after the study have shown the effectiveness of the proposed methodological approaches to the formation of the tutor ICT competence. Implementation of these methodological approaches has become possible due to the introduction of information and educational environment with distance learning technologies and information and communication technologies as its main components.
\end{abstract}

Keywords: professional training; ICT competence; methodological approaches; future teacher; tutor; distance learning; information and communication technologies.

\section{INTRODUCTION}

Today, information and communication technologies offer unprecedented opportunities for rapid dissemination of various types of information (text, numerical, graphic, audio) and digital representation of the main channels of information transmission (audio, visual (static and dynamic)). This causes drastic changes in industry, society and education. Development and implementation of education programs in the field of science, technology, engineering and mathematics are expected to meet the needs of the labor market in highly skilled professionals [1]. This causes a demand for training teachers who have the information and 
communication competence. After all, mastering the competence in the application of information and communication technologies by the younger generation depends on whether teachers will effectively and fully apply them in the educational process. Therefore, the issue of formation of ICT competence of a modern teacher is important, which has been repeatedly mentioned in a number of scientific studies (T. O. Ofoegbu, A.D. Uche, A. P. Dzhurylo, O.M. Shparyk, A. S. Petelin, O.M. Spirin et al.)

Nowadays, the dissemination of ideas of individual, developmental and person-oriented learning, pedagogy of cooperation and partnership actualizes the need to revise the essence of the pedagogical activity. Changes in the model of education, recognition of non-formal and informal education contribute to expanding the range of teachers' functions and roles teachers are expected not only to perform traditional educational functions, but also be able to adjust to the changing requirements of the labour market and the society, to provide pedagogical support of individual educational programs to students of different age. These tasks can be performed by a teacher who has received special training in tutoring activities.

The advent of e-learning and distance learning has changed the functions of the tutor. They should now form and support the individual educational program of the learner, using information and communication technologies. Therefore, the future educators of higher educational institutions need to master the ICT competence and become acquainted with the tools of information technology, which in turn requires elucidation of effective methodological approaches to the development of the ICT competence in future teachers trained for tutoring activities.

Analysis of recent research and publications. Various issues of formation of teachers' ICT competence are featured in numerous scientific studies, for example the research by $\mathrm{T}$. $\mathrm{O}$. Ofoegbu and A.D. Uche [3] revealed that the Basic Science and Technology teachers lacked competence in basic ICT operations. According to A. P. Dzhurylo and O.M. Shparyk [2], teachers need to be equipped with the digital competence, in order to support the process of forming the digital competence inprimary education. A. S. Petelin et al. [4] believe that the most effective mechanism for formation and development of ICT competence of teachers is an educational game. O.M. Spirin [7] determined the structure and place of "information and communication competence" and "informatics competence" in the system of professionalspecialized competence of informatics teachers.

The position of teachers as tutors has been considered in works of T. M. Kovaleva et al. [7], K. P. Osadcha [8], K.W.H. Yung and R. Yuan [9], the position of teachers as tutors in distant education has been described by R. Hampel, U. Stickler [10], S. Bennett, D. Marsh [11]. Not much research deals with the problem of formation of the ICT competence or digital competence of tutors. According to T. Widowati and D. Purwanti [15], the competence of the tutor in ICT should be improved. A. Basantes-Andrade, M. Cabezas-González, and S. Casillas-Martín [16] think that tutors involved in online education programs must have the skills that allow them to overcome the limitations of a virtual environment, using ICT efficiently to support, supervise and facilitate teaching-learning processes. Arguing the significance of ICT competence as a key competence in the context of implementing the basic model of competencies in the digital economy, O.G. Smolyaninova and E.A. Bezyzvestnykh have noted that "the demand of the state, society and stakeholders in tutors who are able to apply relevant ICTs in their professional activity is associated with individualization of education, focus on the students' individual characteristics and educational needs; open character of the educational environment, formation of personal learning environment, and development of e-learning and distance learning technologies" [13]. We share the opinion that the ICT competence is important in the process of professional training of teachers as tutors, that its formation requires the search and implementation of the most promising methodological approaches. 
Therefore, the objective of the article is to clarify the essence and structure of ICT competency of a tutor, to determine and prove the effectiveness of methodological approaches to the formation of ICT competence of future teachers as tutors in the information and educational environment of a higher educational institution.

\section{THE THEORETICAL BACKGROUNDS}

The differences between the notions of computer competence, information competence and ICT competence are semantically significant. According to A. C. Easton and etc. [16], computer competency is another phrase used to describe one's ability to use a computer. This term seems to be most often used by educational institutions that are defining a requirement or proficiency standard. The information competence is the most important component of general professional competence, being an integrated, dynamic evolution of personality, marked by rational style in information activities, related to mastering new information technologies, and capable of creative performance within the educational system [17].

The ICT competence is now considered as a vital competency for all university students to have and is of high priority in every aspect of life for those who want to fit into the digital world [18]. ICT competence has advanced from having the knowledge of basic word processing to the knowledge of spread sheets and internet skills needed to accomplish given tasks within a given time-frame with limited mistakes or no errors [19]. T. O. Ofoegbu and A. D. Uche [3] indicated that the potentials of ICT to improve instruction can help to present information in many forms, make learners feel more confident in the learning process, communicate effectively in any process, become independent learners and good beginners, improve their writing skills, give rise to better problem solving and critical thinking skills.

The tutor ICT competence is understood by us as their ability to perform the professional tasks of tutoring support by means of ICT, which consists of the following stages: 1) determining the cognitive interest of the tutor; 2) formulating the educational request; 3) goal setting of the educational activity; 4) searching educational resources and developing an educational activity plan; 5) implementing and discussing, analysis and adjusting the educational activity plan; 6) analysis of educational results; 7) adjusting educational goals, determining time perspectives [20].

\section{RESEARCH METHODS}

The study has used the content analysis to find out the nature and structure of the tutor ICT competence. This research is a quantitative descriptive study of the tutor ICT competence formation process. Using the Pearson's and Fisher's criteria in the research, the data on the effectiveness of the proposed methodological approaches to building the ICT competence of future teachers as tutors have been received. This research has been conducted in the group of Master's course students of the Bogdan Khmelnitsky Melitopol State Pedagogical University, Ukraine, majoring in "Secondary education (Informatics)". The research was held from September 2016 to June 2019. Data processing uses linked scales from 1 to 3, where 1 is the lowest value, while 3 is the highest value. There are three levels for the results of this study: good, moderate and low according to the scale indicators (3, 2, 1 correspondingly).

\section{THE RESULTS AND DISCUSSION}

1. The structure of the tutor ICT competence. Based on the analysis of scientific works 
on the essence of information and communication competence ([15],[16],[17], [21]), in particular, its formation in future teachers ([4], [5], [6], [13], [14], [22]) and tutors ([10],[11], [12]) we have defined the structure of the tutor ICT competence. In our opinion, it consists of the following skills:

1) knowledge of the educational information resource range and the possibilities of using information and communication technologies in training;

2) information culture and computer literacy acquisition;

3) the ability to apply information and communication technologies in tutoring and for the self-study purposes;

4) comprehension of conceptual statements and basic principles of distance learning;

5) the ability to plan and use the technology of distance learning in the tutoring activity;

6) the ability to adapt and develop e-learning materials;

7) the ability to assist students with the use of ICT for educational purposes;

8) the ability to encourage students to manage their own ICT learning.

Knowledge of the educational information resource range and the possibilities of using information and communication technologies in training provides an overview of the main existing types of ICT and tendencies of their development for the educational process, features of the ICT use for traditional and inclusive learning, with the opportunities of modern information technologies for tutoring activities, in particular, in distance learning, as well as developing the ability to apply modern ICT in the tutoring process in order to increase its effectiveness, to transfer basic necessary knowledge and skills on the expedient use of ICT in the realization of educational goals to students, to encourage students to be critical in the application of ICT to achieve their educational goals.

Information culture and computer literacy acquisition includes knowledge of the role of information in the modern society, acquisition of the deep awareness of ICT by future teachers, mastering the ability to navigate the information flow (to process various types of information and data, use applications and network resources for professional improvement), the ability to dynamic development and self-improvement by obtaining and evaluating information and skills to create knowledge communities, the ability to improve ICT skills and competences independently.

Formation of the ability to apply information and communication technologies in tutoring and for the self-study purposes specifies that tutors should master basic ICT practices that increase productivity (web browsers, communication software, demonstration materials, and management of learning processes, etc.); the ability to use technical means, when working with a group of students or individually, giving the equal access for all participants; the ability to apply ICT at different stages of tutoring; the ability to use professional knowledge communities to collaborate with other teachers, communication with colleagues and specialists.

Comprehension of conceptual statements and basic principles of distance learning (DL) is an important competence in the case of tutoring activities in distance education. Tutors have to know and take into account the conceptual provisions and basic principles of distance education (DE), approaches to the organization of distance learning, technologies and models of distance education; incorporate the results of practice-oriented developments aimed at technologization and informatization of the educational process in their activities. They must have the conceptual understanding of distance course (DC) design, which involves the ability to formulate the purpose, objectives and expected learning outcomes, to select education content, forms, methods and means of training, as well as diagnostic tools in accordance with the tasks of tutoring support, to plan control activities. Also, it is important to be acquainted with legislative and regulatory acts concerning the educational process in Ukraine and abroad, 
modern pedagogical and philosophical concepts.

Implementation of the ability to plan and use the technology of distance learning in the tutoring activity requires the knowledge of learning theories and their impact on teaching and learning with the help of distance learning: principles of selection of appropriate methods of distance learning; learning ways based on distance learning technologies and appropriate training strategies; distance learning goals; available distance learning technologies to support tutors; ways of presenting information in a format that allows students to better understand it without direct interaction with the tutor. Future teachers need to be able to identify the best ways to apply distance learning means to support the goals of students' individual educational programs, taking into account their abilities, learning styles and available organizational means. Students have to learn to identify sources of materials that satisfy their actual and anticipated needs at the higher education institution; set criteria for educational materials; create a set of materials, including education materials for students with disabilities; format the materials in order to make them suitable for distance learning under copyright and licensing agreements; monitor student reactions to distance learning programs in order to ensure that training materials are correspondent to their abilities and learning styles; evaluate the effectiveness of teaching materials in meeting learning goals for students with diverse needs and opportunities; choose the proper conditions of distance learning; monitor information about student participation in distance learning and their achievements; use appropriate tools to record student progress and achievements; use distance learning technology to automate reporting.

In order to form the ability to adapt and develop e-learning materials, future teachers have to learn how to develop study materials on their own or collaborate with subject experts and designers. Also, they should develop plans and requirements for training materials in terms of content, training goals and training strategies, as well as develop prototypes of training materials and present them to a group of users. It is important to be able to properly structure learning materials to promote curiosity, creativity, strengthen knowledge and understanding of the investigated phenomena and processes.

Formation of the ICT competence of future teachers also involves mastering the ability to assist students with the use of ICT for educational purposes. To do this, they have to know the appropriate ways of learning and learning strategies, which are advisable to use by means of ICT; approaches, that can be used to identify student needs in ICT applications; methods of assessment and ways of achieving educational learning goals through ICT; ICT functions to facilitate the realization of the student opportunities.

The ability to encourage students to manage their own ICT learning means that future teachers have to know possibilities of ICT and ICT-based learning methods, the relationship between learning styles and the necessary results, methods to support students in identifying their own learning needs, and how to use ICT to help students manage the process of achieving their educational goals. The tutor needs to be able to facilitate the use of appropriate tools and Internet services for the purpose of training by analyzing students' needs, use ICT as an indicator of learning opportunities, support students in choosing ICT-based learning opportunities, use ICT to help review training plans.

2. Methodological approaches for forming the tutor ICT competence. The formation of the tutor ICT competence has been carried out by means of the study of the relevant educational content, the use of specific methods, tools and technologies in an information and educational environment.

The educational content, aimed at forming the ICT competence of teachers as tutors, is distributed over the entire period of students' study at the higher educational institution. In the 1st year, during the study of the "Fundamentals of Informatics", students are offered to study 
the "Distance Learning Platforms" topic, which introduces to future tutors modern systems of distance learning such as Moodle, Lotus Learning Space, Blackboard Learning System, REDCLASS and others. In the 2nd year, in the course of Pedagogy, the students study the topic "The concept of distance learning", which covers the essence of distance learning and technologies, in particular technologies of collaborative and cooperative learning, project technologies, technologies of problematic, individual and differentiated learning, game technologies and differentiated learning. In the 3rd year, in the course of "Pedagogical Skills" students are introduced to the features of developing a student individual educational program under the conditions of distance learning. In the 4th year, during the study of teaching methods, the topic "Design and development of distance courses" is introduced. In addition, in the final year students can write their qualification works on the issues of the organization of tutor support.

In order to form the ICT competence of future tutors in Master's course students, the discipline "Organization of distance learning at an educational institution" [23] was introduced. Its purpose is to teach students how to develop distance courses and organize distance education in general secondary and higher education institutions. In 2016-2019 students majoring in 014.09 "Secondary education. Informatics" studied the proposed discipline using distance technologies.

Thus, students of both educational levels (Bachelor's and Master's) are exposed to the relevant educational content aimed at forming their ICT competence.

Formation of the ICT competence of future teachers as tutors requires appropriate selection of methods. Here, we believe that the portfolio method can be appropriate. Its application is intended to teach students to create their own portfolios. There are several types of portfolios in the practice of tutoring: thematic, presentation portfolios, portfolios of achievements. A portfolio is kept by a student for several years. Students accumulate materials, structure and modify them. The portfolio helps students to track the stages of their educational trajectory and is an effective self-assessment tool for them [7]. The portfolio of achievements which helps to assess the learning process progress is of greater importance to the professional activity than the ordinary portfolio. The portfolio of achievements may include: originals or copies of creative works; feedback and reviews of teachers and external experts working in a specific area of interest; peer reviews, reviews of classmates, etc.; excerpts from the academic registers, rating screens, etc.; tutor cover letters: evaluation of work and description of prospects for further development; a student's resume: a short description of the most important results achieved in this work, etc.

It is advisable to use an electronic portfolio as a strategy for evaluating student achievements. As an alternative assessment type, the portfolio method is widely used for project-based learning because its components are "the reflections of students during different periods, improvement in their progress, and prospective goals" [24]. An electronic portfolio is one that is collected, saved, and stored in an electronic digitized format. According to T. Batson [25], an electronic portfolio (e-portfolio) is a collection of student works at a Web site that interfaces with a database of student work artifacts. A standard-based portfolio uses a database or hypertext links to clearly show the relationship between the standards or goals, artifacts and reflections. By the use of e-portfolios, students have the chance to reflect upon their learning and teachers have the opportunity to provide detailed feedback on students' work [26]. According to L.L. Lynch and P. Purnawarman, "one unique aspect of the electronic portfolio assessment is the demonstration of critical thinking through reflective writing about artifact construction, selection and revision" [27].

In the process of formation of the ICT competence of future teachers as tutors, traditional teaching aids are complemented with innovative pedagogical ICT developments, including computer training programs, e-resources, web resources, mobile applications, 
virtual and augmented reality tools. Visualization technologies are also used, asthe process of using different forms of information through a variety of verbal, visual, multimedia codes, such as subject, word, abbreviation, drawing, drafting, graphics, graph diagrams, icons, symbol, number, model, experience contributes to the activation of learning activity, its support, intensification of the process of comprehension and information processing [28]. Most commonly used technologies are information visualization and knowledge visualization. Visualization of information involves the transformation and presentation of abstract data in a form that will improve their perception and understanding. Such tools as different types of graphs and charts (linear, columnar, circular, planar, circular, petal, etc.) can be used. Knowledge visualization is intended to be used for visual representation of knowledge to improve its understanding, focuses on the transfer of ideas and the creation of new knowledge in groups and aims to transfer ideas, experiences, relationships, values, trends, thoughts and forecasts, using a variety of additional visualizations (picture dictionaries, visual dictionaries). Knowledge visualization helps to overcome the information overload, to create accurate formulations and to understand the best way to move for the goal [29]. In practice, it is advisable to use modern imaging techniques that can be used in the learning process to refine textual information through ICT, namely: word clouds (tags) using Tagul, Worditout, Tagxedo, WordCloud Internet services; intellectual maps (mind maps, knowledge maps, concept maps, mental maps) - MindManager Pro and Mind Manager software tools and Freemind and Mindmeister online resources; scribing -VideoScribe programs; comics Toondoo, Pixton, ComicLife Internet services; Stiteling - ZooBurst, StoryBird online resources; infographics - Internet-services like Piktochart, Easel.ly, Infogr.am, Visual.ly, etc.

In order to optimize the process of professional training of future teachers for tutor activities, it is important to introduce interaction technologies, including networking, which is done through the joint use of information, electronic, teaching and educationalmethodological resources. E-mail, blogs, social networks, webinars, chats are used as networking means. A new form of networking organization is online communities, where future teachers enhance their professional level and communicate with experienced educators and experts to address professional issues. The teacher invites students to the professional networking community, organizes them for distance competitions, conferences, contests, workshops, etc., directs their activities in network projects. Being active in online professional communities will allow future teachers to acquire professional and distance learning skills, communication skills to gain and transfer pedagogical experience, skills in student support through modern ICT and creating an information educational environment.

3. Structure of the information and educational environment. According to the analysis of scientific works on the organization of the educational process with ICT application [30],[32], and preparing teachers for the ICT use in their professional activity [2], $[5],[31],[34]$ we have determined the structure of the information and educational environment consisting of two groups of ICT: distance learning technologies (including adaptive ones) and ICT with division into general and tutorial facilities. The first group includes adaptive learning management systems, learning management systems, content management systems, personal learning environments, and computer learning systems. The second group comprises general-purpose information and communication technologies technologies of presentation of educational information, technology of storage and processing of educational information, technology of transfer of educational information, technology of interaction between participants of the educational process, technology of control and evaluation of student educational achievements. Among the information and communication technologies of tutorial support, we have determined the following ones: technologies for determination of the cognitive interest (computer and online testing, test constructors), 
formulation of an educational request (online boards, intellect cards), for the purpose statement of carrying out educational activities (planners, organizers, calendars), for the search of educational resources and developing educational activity plans (search tools, information aggregators, repositories of graphics and video, software and services for creating multimedia content), for implementation and discussion, analysis, and adjustment of the educational activity plan (office programs, portfolio services, e-book services), for the analysis of the results of educational activities (programs for the creation of training materials, development and testing), for adjustment of the educational goals, determination of prospects ("brainstorming" tools, goal management systems, electronic presentations, spreadsheets).

These technologies have been widely used in the process of educating teachers to form their ICT competence. Specifics of tutoring activities in the context of distance learning depend on the variety of tools used by tutors to implement the distance learning process. These technologies have to be mastered by future teachers in the training process. One of the most common approaches to teaching the ICT use is their everyday use by teachers, along with tutorial support of students. Thus, the teacher demonstrates both an example of work with ICT and methods of their application in the tutoring activities.

At each stage of tutoring in the process of preparing future teachers for tutoring activities, a teacher may benefit from certain types of ICT. So, at the first stage - the determination of cognitive interest - the teacher can use testing software or online tests, for example, the "Holomstok Interest Map" (http://onlinetestpad.com), "Multistage Professional Interest Questionnaire" or "Identifying Cognitive Interests" (http://profi.org.ua/tests.shtml) online tests and others. The teachers can design tests themselves using test constructors such as Master Test, TestTurn, Let's Test, Google Shape, Simpoll etc., and invite undergraduate students to complete them offline or online.

At the second stage of the tutorial support, which involves formulating an educational request, the teacher may use programs or online services to "brainstorm". These include online boards (Realtimeboard, Whiteboard, Edistorm), which are workspaces for adding notes, illustrations, pictures, texts, diagrams, comments, etc. so that participants understand each other better. A great feature of such a resource as Edistorm is an opportunity to vote for an idea, topic, or issue, and Edistorm automatically identifies the best ideas. So, not only the tutor and student can participate in this process, but also parents and other interested parties (psychologists, subject teachers). It is also possible to use online smart cards at this stage (XMind, MindMeister, Mapul, iMind Map, coggle.it etc.), which are convenient tools for visualizing and documenting the process of implementing ideas.

The third stage of the tutor support involves setting the goal of an educational activity as a way of the expected result. It is formulated by the tutor and a student. It is advisable to use software to set and achieve goals. They are presented in the form of desktop, mobile and online applications. In the software industry, there are numerous planners, organizers, calendars and more. Thus, the SmartProgress service and mobile app let tutors create and publish goals, divide goals into stages, keep track of achievements, subscribe to and track other people's goals.

The most universal software tools for such tasks are organizers, which help tutors plan activities for long terms. For instance, MyLifeOrganized, as a system for managing tasks, projects and goals gives users the ability to make a list and hierarchy of tasks, remind about them, plan the time for their execution. This is a powerful tool for effective management of educational goals. For school-age children, it might be advisable to use a game planner, such as Life RPG, where students will be rewarded for their accomplishments, or Habit RPG, where the student becomes a player, completing missions, earning points for their achievements and losing them for their defeats, have the ability to compete with other players and share responsibility for scheduled affairs. 
To illustrate work plans and work schedules, a Gantt chart is often used, which reflects tasks, their duration, their beginning and ending in the graphical form. Tutors can use special software in their activities (such as Microsoft Project, Microsoft Excel, GanttProject, etc.) or online services (GanttPro) to compile a Gantt chart to illustrate the process of achieving the goal of the educational activity by splitting it into tasks and taking time to complete them.

At the fourth stage of the tutor support, which involves searching educational resources and developing a plan of educational activity, it becomes necessary to have a powerful tool for collecting information of various kinds (text, graphics, video, multimedia), its structuring and organizing for the purpose of further planning of the tutor and student activities. At first, the tutor has to search for information. Because of the fact that nowadays the information resources on the Internet comprise more than ten million documents (web-pages), which offer free access for any users, it is advisable to search for educational resources by means of information search engines (Google, Yahoo, Bing, Baidu). It is possible to use specific search tools to search for specific types of content, such as the Google search engine (search for images, videos, news, books, apps), or separate resources for each type of information (for video hosting, images - image directory, etc.); aggregators of information (e.g., Feedly); delayed reading services (for example, Pocket, Readability, Flipboard) allowing users to save interesting web content and read it at any convenient time, including offline; image storage and sharing services (Flickr, Pinterest, Instagram); video hosting services (YouTube, TeacherTube, EDX, SchoolTube).

However, it should be noted that working with a whole range of different programs can complicate the tutoring activities, so we consider it more appropriate to use the services for creation of training materials when processing large arrays of educational resources. For example, such a simple and functional program as MOS Solo presents many opportunities for creating multimedia educational content, interactive graphic e-courses, polls and demonstrations. It has a built-in translation tool for different languages and the ability to develop for iPad, iPhone, Android, Windows, which allows to expand the availability of educational materials. Another example is the Smart Builder service, which allows users to create e-learning courses with media content and game elements without programming skills. These programs are eAuthor CBT, CourseLab, Microsoft LCDS, the services include Udutu, Zenler, Lesson Writer and others.

The fifth stage of the tutor support involves the realization, discussion, analysis and correction of the educational plan, where the collection of the portfolio is the basis. A student's portfolio can be developed using such applications as Microsoft PowerPoint, LibreOffice Impress, Microsoft Word, LibreOffice Writer, or special online services for its creation, such as uPortfolio, as well as e-book services (such as Albooka, Calameo, Issuu, Glogster).

At the sixth stage, when analyzing the results of educational activities, users can use programs or testing services, by means of which the teacher can test students' knowledge, the results of the development of certain skills, habits and personality traits. Among these programs and services are CourseLab, Microsoft LCDS, which have a testing module, Hot Potatoes, easyQuizzy, ADTester, ProProfs, Quiz Maker, Simpoll, etc.

At the seventh stage of the tutor support, tools for "brainstorming" and goal management systems to adjust the educational goal and determine the prospects, as well as electronic presentations to present educational achievements, spreadsheets to compare plans and results achieved can be re-used.

Thus, different information and communication tools may be used to build the ICT competence of future tutors. They allow tutors to optimize learning activities, diversify the educational process, and make it open to all interested parties. 
4. Examining the effectiveness of methodological approaches for forming the ICT competence of future teachers as tutors. A pedagogical experiment has been conducted to prove the effectiveness of the proposed methodological approaches to the formation of the ICT competence of future teachers as tutors, which was to introduce the proposed teaching content, methods, tools and technologies.

59 Master students (29 students of the control group, CG, 30 students of the experimental group, EG) were involved in conducting the forming experiment. To study the level of their ICT competence, we developed a questionnaire consisting of 22 closed-ended questions aimed at self-assessment of the skills that are part of the proposed structure of the ICT competence. The procedure for processing the results was to match the answers of the respondents with the key and to score points as follows: 2 points for answer A, 1 point for answer B, 0 point for answer $\mathrm{C}$. If a respondent scored from 0 to 15 points, we considered that they had a low level of ICT competence, if the result was from 16 to 29 points, the level was considered to be average, from 30 to 44 points it was considered to be high.

The analysis of the results (Table 1) of assessing the level of the ICT competence of students of CG and EG at the beginning of the experiment showed that 12 students $(40 \%)$ in the control group and 15 students $(50 \%)$ in the experimental group had average and high levels of the ICT-competence. Such data attests to the homogeneity of CG and EG.

The analysis of the results of assessment of the level of ICT competence formation after applying the proposed methodological approaches (Table 2) showed the heterogeneity for CG and EG.

Table 1

Level of formation of the information literacy and tutoring skills in using ICT of CG and EG students at the beginning of the experiment

\begin{tabular}{|l|l|l|l|l|l|l|}
\hline \multicolumn{2}{|c|}{ Level High } & \multicolumn{2}{c|}{ Average } & \multicolumn{2}{c|}{ Low } \\
\hline $\begin{array}{l}\text { Groups / Units } \\
\text { measurement }\end{array}$ & Quantity & $\%$ & Quantity & $\%$ & Quantity & $\%$ \\
\hline CG & 2 & 6,9 & 10 & 34,48 & 17 & 58,62 \\
\hline EG & 3 & 10 & 12 & 40 & 15 & 50 \\
\hline
\end{tabular}

The comparative analysis of the ICT competence indices for control and experimental groups at the end of the experiment was performed using two criteria - Fisher's criterion and $\chi 2$ homogeneity criterion (Pearson's criterion).

Table2

Level of formation of the information literacy and tutoring skills in using ICT of CG and EG students at the end of the experiment

\begin{tabular}{|l|l|l|l|l|l|l|}
\hline \multicolumn{2}{|c|}{ Level } & \multicolumn{2}{c|}{ High } & \multicolumn{2}{c|}{ Average } & \multicolumn{2}{c|}{ Low } \\
\hline $\begin{array}{l}\text { Groups / Units } \\
\text { measurement }\end{array}$ & Quantity & $\%$ & Quantity & $\%$ & Quantity & $\%$ \\
\hline CG & 3 & 10,34 & 11 & 37,93 & 15 & 51,72 \\
\hline EG & 5 & 16,67 & 19 & 63,33 & 6 & 20 \\
\hline
\end{tabular}

To analyze the data obtained in the empirical study (coincidence or differences in the characteristics of the experimental and control groups), two statistical hypotheses were formulated: 
- the hypothesis of no differences $\left(\mathrm{H}_{0}\right.$ null hypothesis $)$ in the control and experimental groups;

- the hypothesis of the difference significance $\left(\mathrm{H}_{1}\right.$ alternative hypothesis $)$ in the control and experimental groups.

By checking the results of ICT competence formation using the Fischer test, it has been found that at the beginning of the experiment for the $\mathrm{CG}$ and $\mathrm{EG}$, the indicators of the middle and low levels did not differ $\left(\varphi_{\text {еми }}=0,438, \varphi_{\text {емn }}=0,664\right.$ respectively). After the experiment, the indicators for the middle level differed significantly $\left(\varphi_{\text {enn }}=1,97\right)$, which is more than the critical value $\left.\varphi_{k p}=1,64\right)$, as did the indicators for the low level $\left(\varphi_{\text {exn }}=2,604\right)$.

Comparison of results by Pearson's criterion at the beginning of the experiment made it possible to conclude that there were no significant differences in these samples $\left(\chi_{e x n}^{2}=0,52\right.$; $\left.\chi_{k p}^{2}=5,99\right)$. Comparison of the results at the end of the experiment revealed the differences between these samples, as $\chi_{\text {enn }}^{2}=6,71$ evidenced.

Therefore, after analyzing the data on determining the level of the ICT competence at the beginning of the experiment, the null hypothesis $\left(\mathrm{H}_{0}\right)$ about no differences in the control and experimental groups is accepted. Further, after introducing the content, methods, tools and technologies for the formation of the ICT competence for future teachers as tutors, and after analyzing the data to determine the level of ICT competence formation at the end of the experiment, an alternative hypothesis is adopted $\left(\mathrm{H}_{1}\right)$ about the significance of differences in control and experimental groups. This proves the effectiveness of the proposed methodological approaches to building the ICT competence of future teachers as tutors.

\section{CONCLUSIONS AND PROSPECTS FOR FURTHER RESEARCH}

In conclusion, it should be stated that, in order to ensure the sustainable development of society in the future, it is necessary to build the ICT competence of future teachers as tutors who should effectively apply ICT in their professional activities, making teaching more successful and engaging. The identification and characterization of the skills that make up the ICT competence of the tutor, the introduction of the content, methods, tools and technologies for the formation of ICT competencies allowed us to conduct a pedagogical experiment to determine the effectiveness of the proposed methodological approaches. The results of the experiment were based on the questionnaire survey of Master's course students. The questions of the survey were aimed at the determination of the level of the development of each skill which is part of the ICT competence. The analysis of the results of the pedagogical experiment on the basis of the comparison of indicators of control and experimental groups before and after the study has shown the effectiveness of the proposed methodological approaches (content, methods, tools and technologies) to the formation of the ICT competence for future teachers as tutors. Prospects for further research are seen in the analysis of the possibilities of using virtual and augmented reality technologies in the training of teachers as tutors.

\section{REFERENCES (TRANSLATED AND TRANSLITERATED)}

[1] V. Osadchyi, N. Valko, N. Kushnir,"Determining the Level of Readiness of Teachers to Implementation of STEM-Education in Ukraine," in Proc. 15th International Conference ICT in Education, Research and Industrial Applications: Integration, Harmonization and Knowledge Transfer, Kherson,Ukraine, June 12-15, 2019,pp. 144-155. [Online].Available: http://ceur-ws.org/Vol-2393/paper_369.pdf.Accessed on: April 13, 2020(in English)

[2] A.P. Dzhurylo, O. M. Shparyk, "ICT competence for secondary school teachers and students in the context of education informatization:global experience and challenges for Ukraine," Information Technologies and 
Learning Tools, vol. 70, no. 2, pp. 43-58, 2019. doi:https://doi.org/10.33407/itlt.v70i2.2438. (in English)

[3] T.O. Ofoegbu, A.D. Uche, "Information and Communication Technology Competencies of Lower and Middle Basic Science and Technology Teachers in Enugu State," Journal of Educational Media and Technology, vol. 2, no. 11, pp. 17-28. 2013 (in English)

[4] A.S. Petelin, O.V. Galustyan, T.S. Prosvetova, E.A. Petelina, A.Y. Ryzhenkov, "Application of educational games for formation and development of ICT competence of teachers," International Journal of Emerging Technologies in Learning, vol. 14, no. 15, pp. 193-201, 2019. doi:http://dx.doi.org/10.3991/ijet.v14i15.10572. (in English)

[5] E. Smyrnova-Trybulska, "Theoretical and methodological bases of information competences for teachers in the field of distance learning," Theory and methods of learning mathematics, physics, informatics, vol. 7, no. 3, pp. 4-14, 2008(in Ukrainian)

[6] O.M. Spirin, "Information and communication and informatics competences as component of the system of professional-specialized competences of informatics teacher," Information Technologies and Learning Tools, vol. 3, no. 5, 2009. doi: https://doi.org/10.33407/itlt.v13i5.183. 2008(in Ukrainian)

[7] T.M. Kovaleva, E.I. Kobyshcha, S.Y. Popova (Smolik), A.A. Terov, M.Y. Cheredilinaб, Profession "Tutor," Moscow-Tver, Russia: SFK-office, 2012 (in Russian)

[8] K.P. Osadcha, "Tutor support of teaching mathematics with information and communication technologies," Information Technologies and Learning Tools, vol. 61, no. 5,pp. 36-49, 2017. doi: https://doi.org/10.33407/itlt.v61i5.1693. (in Ukrainian)

[9] K.W.H. Yung, R. Yuan, "'The most popular star-tutor of English': discursive construction of tutor identities in shadow education," Discourse: Studies in the Cultural Politics of Education, vol. 41, no. 1, pp. 153-168, 2020. doi: https://doi.org/10.1080/01596306.2018.1488241. (in English)

[10] R. Hampel, U. Stickler, "Online teaching skills for language tutors," Subject Centre for Languages. Linguistics and Area Studies. Good Practice Guide, 2008. [Online]. Available: https://www.llas.ac.uk/resources/gpg/2530. Accessed on: April 10, 2020 (in English)

[11] S. Bennett, D. Marsh, “Are We Expecting Online Tutors to Run Before They Can Walk?", Innovations in Education and Teaching International, vol. 39, no. 1, pp. 14-20, 2002.doi: https://doi.org/10.1080/13558000110097055. (in English)

[12] G. Salmon, E-Moderating: The Key to Online Teaching and Learning, New York, USA: Routledge, 2011 (in English)

[13] O.G. Smolyaninova, E.A. Bezyzvestnykh, "Professional training of teacher 4.0: Developing digital competency by means of ePortfolio," Journal of Siberian Federal University - Humanities and Social,vol. 12, no. 9, pp. 1714-1732, 2019. [Online]. Available: http://journal.sfu-kras.ru/en/article/125589. Accessed on: April 09, 2020 (in English)

[14] T. Widowati, D. Purwanti, "The enhancement model of ICT competence for the teachers of SMP Terbuka in Central Java to support long distance learning program," AIP Conference Proceedings, vol. 1818, no. 1, 20070, 2017.doi: https://doi.org/10.1063/1.4976934. (in English)

[15] A. Basantes-Andrade, M. Cabezas-González, S. Casillas-Martín, "Digital Competences in e-learning.Case Study: Ecuador," Technology, Sustainability and Educational Innovation (TSIE).TSIE 2019.Advances in Intelligent Systems and Computin, vol. 1110, pp. 85-94, 2020.doi: https://doi.org/10.1007/978-3-030-372217_8. (in English)

[16] A.C. Easton, G. Easton, T. Addo, "But I am computer literate: I passed the test," Journal of College Teaching and Learning, vol. 3, no. 2, pp. 9-44, 2006. doi: https://doi.org/10.19030/tlc.v3i2.1746. (in English)

[17] A. Zhumasheva, Z. Zhumabaeva, J. Sakenov, Y. Vedilina, N. Zhaxylykova, B. Sekenova,"Theoretical Model of Development of Information Competence among Students Enrolled in Elective Courses," International Journal of Environmental and Science Education, vol. 11, no. 18, pp. 11249-11259,2016(in English)

[18] J.C. Nwosu, H.C. John, A.A. Izang, O.J. Akorede, “Assessment of Information and Communication Technology (ICT) Competence and Literacy Skills among Undergraduates as a Determinant Factor of Academic Achievement," Educational Research and Reviews,vol.13, no. 15, pp. 582-589,2018. doi: https://doi.org/10.5897/ERR2018.3539. (in English)

[19] B.A. Adeyemi, "Self Concept and Motivation Variables as Correlates of Acquisition of ICT Competence among Social Studies Students of ObafemiAwolowo University, Ile-Ife, Nigeria.” World Journal of Education, vol. 4, no. 2, pp. 76-82, 2014. doi:https://doi.org/10.5430/wje.v4n2p76. (in English)

[20] N.V. Pilipchevskya, V.A. Adolf,"The tutorial support socio-pedagogical adaptation of the students," Siberian Pedagogical Journal, vol. 12, pp. 134-141,2009.[Online]. Available: https://www.elibrary.ru/item.asp?id=16357020. Accessed on: April 11, 2020 (in Russian)

[21] D.W. Johnson, K.W. Bartholomew, D. Miller,"Improving Computer Literacy of Business management majors: A case study",Journal of Information Technology Education: Research,vol. 5, pp. 77-094,2006.doi: https://doi.org/10.28945/235. (in English) 
[22] J. Purnomo, Jailani, "ICT literacy of high school mathematics teacher: Online learning competence with heutagogical approach," Journal of Physics: Conference Series,vol. 1321, no. 3, 2019.[Online]. Available: https://iopscience.iop.org/article/10.1088/1742-6596/1321/3/032128/pdf. Accessed on: April 11, 2020 (in English)

[23] K.P. Osadcha, "Content of the discipline for professional preparation of future teachers to the tutor activity," in Proc. International research and practice conference "Modern methods, innovations and operational experience in the field of psychology and pedagogics”, Lublin, Poland, 2017, pp.73-76 (in English)

[24] Y. Gülbahar, H. Tinmaz, "Implementing Project-Based Learning And E-Portfolio Assessment In an Undergraduate Course," Journal of Research on Technology in Education, vol. 38, no. 3, pp. 309-327,2006. doi: https://doi.org/10.1080/15391523.2006.10782462. (in English)

[25] T. Batson, "The Electronic Portfolio Boom: What's It All About?",Campus Technology, 2002. [Online]. Available: https://campustechnology.com/Articles/2002/11/The-Electronic-Portfolio-Boom-Whats-it-AllAbout.aspx?Page=2. Accessed on: April 12, 2020 (in English)

[26] J. Ahn, "Electronic portfolios: Blending technology, accountability and assessment," T.H.E. Journal, vol. 31, no. 9, pp. 12-18, 2004 (in English)

[27] L.L. Lynch, P. Purnawarman, "Electronic portfolio assessments in u.s. educational and instructional technology programs: Are they supporting teacher education?",TechTrends,vol. 48, no. 1, pp. 50-56, 2004. doi: https://doi.org/10.1007/BF02784865. (in English)

[28] O. Babich,"Visualization of information in the learning process," Physical and mathematical education,vol. 1, no. 5, pp. 167-170, 2013(in Ukrainian)

[29] V.V. Osadchyi, K.P. Osadcha, "Information and communication technologies in the process of future teachers'visual thinking development," Scientific Bulletin Melitopol State Pedagogical University. Series: Pedagogy,vol. 1, no. 12, pp. 128-133,2014 (in Ukrainian)

[30] O.V. Spivakovskyi, M.O. Vinnyk, Y.H. Tarasich,"To the problem of ICT management in higher educational institutions," Information Technologies and Learning Tools, vol. 39, no. 1, pp.99-116, 2014. doi: https://doi.org/10.33407/itlt.v39i1.996. (in Ukrainian)

[31] I. Naumuk,N. Korzun, "Features of the use of elements of distance learning in the process of training future teachers of computer science," Ukrainian Journal of Educational Studies and Information Technology, vol. 6, no. 3, pp. 70-80,2015. doi:https://doi.org/10.32919/uesit.2018.03.07. (in Ukrainian)

[32] V. Yu. Bykov, "The theoretical and methodological ground for modeling of educational environment of modern pedagogic systems," Information Technologies and Learning Tools, vol. 1, no. 1, 2006.[Online]. Available:https://journal.iitta.gov.ua/index.php/itlt/article/view/285. Accessed on: April 14, 2020 (in Ukrainian)

[33] M. P. Shyshkina,“Tendencies of development and use of information technologies in the context of formation of the educational environment," Information Technologies and Learning Tools, vol. 1, no. 1, 2006.[Online]. Available:https://journal.iitta.gov.ua/index.php/itlt/article/view/287. Accessed on: April 14,2020 (in Ukrainian)

[34] O. Ovcharuk, "Attitude of Ukrainian Educators toward the Use of Digital Tools for Teaching and Professional Development: Survey Results." ICTERI-2020: 16th International Conference on ICT in Research, Education and Industrial Applications. Volume II: Workshops. Kharkiv, Ukraine, October 06-10, 2020. pp. 746755.[Online]. Available: http://ceur-ws.org/Vol-2732. (in English)

Text of the article was accepted by Editorial Team 24.07.2020

\title{
ФОРМУВАННЯ ІКТ-КОМПЕТЕНТНОСТІ ТЬЮТОРА В ПРОЦЕСІ ПРОФЕСІЙНОЇ ПІДГОТОВКИ МАЙБУТНІХ УЧИТЕЛІВ
}

\author{
Сисосва Світлана Олександрівна \\ Відділення загальної педагогіки та філософії освіти НАПН України, \\ Національна академія педагогічних наук України, м. Київ, Україна \\ ORCID ID 0000-0003-2499-732X \\ s.sysoieva@kubg.edu.ua
}

доктор педагогічних наук, професор, дійсний член (академік) НАПН України, академік-секретар

\section{Осадча Катерина Петрівна}

кандидат педагогічних наук, доцент, доцентка кафедри інформатики і кібернетики

Мелітопольський державний педагогічний університет ім. Б. Хмельницького, м. Мелітополь, Україна ORCID ID 0000-0003-0653-6423

okp@mdpu.org.ua 


\begin{abstract}
Анотація. Широке поширення інформаційно-комунікаційних технологій i забезпечення сталого розвитку через подолання нерівномірного доступу підростаючого покоління до інформаційно-комунікаційних технологій вимагає від майбутніх учителів високого рівня IКТ-компетентності та вміння здійснювати тьюторську діяльність в умовах інформаційного суспільства. У статті авторами запропоновано методичні підходи (зміст, методи, засоби, технології) формування ІКТ-компетентності тьютора в процесі професійної підготовки майбутніх учителів. Зміст навчання, спрямованого на формування ІКТ-компетентності вчителів як тьюторів, розподілено на весь період навчання студентів в ЗВО. Він передбачає ознайомлення 3 питаннями застосування IКТ в тьюторській діяльності при вивченні обов'язкових дисциплін на бакалавраті і варіативної дисципліни «Організація дистанційного навчання в навчальному закладі» у магістратурі. Як основний метод формування ІКТ-компетентності тьютора визначено метод портфоліо, зокрема робота 3 електронним портфоліо при навчанні в ЗВО. Як основні засоби формування ІКТкомпетентності тьютора виділені комп'ютерні навчальні програми, електронні ресурси, ресурси мережі Інтернет, мобільні додатки, віртуальна i доповнена реальність. Як технології мережевої взаємодії для формування ІКТ-компетентності тьютора застосовувались електронна пошта, блог, соціальна мережа, вебінари, чати. 3 метою виявлення ефективних методичних підходів формування ІКТ-компетентності майбутніх учителів як тьюторів дослідження проводилось на основі збору інформації шляхом анкетування i статистичної обробки результатів. Аналіз результатів проведеного педагогічного експерименту і зіставлення показників контрольної та експериментальної груп до і після проведення дослідження показали ефективність запропонованих методичних підходів до формування ІКТ-компетентності тьюторів. Реалізація зазначених методичних підходів стала можливою за умови впровадження інформаційно-освітнього середовища, основною частиною якої стали технології дистанційного навчання та інформаційнокомунікаційні технології.
\end{abstract}

Ключеві слова: професійна підготовка; ІКТ-компетентність; методологічні підходи; майбутній учитель; тьютор; дистанційне навчання; інформаційно-комунікаційні технології.

\title{
ФОРМИРОВАНИЯ ИКТ-КОМПЕТЕНТНОСТИ ТЬЮТОРА В ПРОЦЕССЕ ПРОФЕССИОНАЛЬНОЙ ПОДГОТОВКИ БУДУЩИХ УЧИТЕЛЕЙ
}

\author{
Сысоева Светлана Александровна \\ доктор педагогических наук, профессор, действительный член (академик) НАПН Украины, академик- \\ секретарь Отделения общей педагогики и философии образования НАПН Украины, \\ Национальная академия педагогических наук Украины, г. Киев, Украина \\ ORCID ID 0000-0003-2499-732X \\ s.sysoieva@kubg.edu.ua
}

\section{Осадчая Екатерина Петровна}

кандидат педагогических наук, доцент, доцент кафедры информатики и кибернетики

Мелитопольский государственный педагогический университет им. Б. Хмельницкого, г. Мелитополь, Украина

ORCID ID 0000-0003-0653-6423

okp@mdpu.org.ua

\begin{abstract}
Аннотация. Широкое распространение информационно-коммуникационных технологий и обеспечение устойчивого развития через преодоление неравномерного доступа подрастающего поколения к информационно-коммуникационным технологиям требует от будущих учителей высокого уровня ИКТ-компетентности и умения осуществлять тьюторскую деятельность в условиях информационного общества. В статье авторами предложены методические подходы (содержание, методы, средства, технологии) формирования ИКТ-компетентности тьютора в процессе профессиональной подготовки будущих учителей. Учебное содержание, направленное на формирование ИКТкомпетентности учителей как тьюторов, распределено на весь период обучения студентов в ВНЗ. Оно предусматривает ознакомление с вопросами применения ИКТ в тьюторской деятельности при изучении обязательных дисциплин на бакалавриате и вариативной дисциплины «Организация дистанционного обучения в учебном заведении» в магистратуре.
\end{abstract}


В качестве основного метода формирования ИКТ-компетентности тьютора определен метод портфолио, в частности работа с электронным портфолио при обучении в ВНЗ. Как основные средства формирования ИКТ-компетентности тьютора выделены компьютерные обучающие программы, электронные ресурсы, ресурсы сети Интернет, мобильные приложения, виртуальная и дополненная реальности. Как технологии сетевого взаимодействия для формирования ИКТ-компетентноститьютора применялись электронная почта, блог, социальная сеть, вебинары, чаты. С целью выявления эффективных методических подходов формирования ИКТ-компетентности будущих учителей как тьюторов исследование проводилось на основе сбора информации путем анкетирования и статистической обработки результатов. Анализ результатов проведенного педагогического эксперимента и сопоставление показателей контрольной и экспериментальной групп до и после проведения исследования показали эффективность предложенных методических подходов к формированию ИКТ-компетентности тьюторов. Реализация указанных методических подходов стала возможной при условии внедрения информационнообразовательной среды, основной частью которой стали технологии дистанционного обучения и информационно-коммуникационные технологии.

Ключевые слова: профессиональная подготовка; ИКТ-компетентность; методологические подходы; будущий учитель; тьютор; дистанционное обучение; информационнокоммуникационные технологии.

\section{(c) $)$ EY-NC-SA}

This work is licensed under Creative Commons Attribution-NonCommercial-ShareAlike 4.0 International License. 